\title{
Curcumin ameliorates high-fat diet-induced spermatogenesis dysfunction
}

\author{
YANG MU*, WEN-JIE YAN*, TAI-LANG YIN and JING YANG \\ Reproductive Medical Center, Renmin Hospital of Wuhan University, Wuhan, Hubei 430060, P.R. China
}

Received May 13, 2015; Accepted February 25, 2016

DOI: $10.3892 / \mathrm{mmr} .2016 .5712$

\begin{abstract}
Curcumin, a type of natural active ingredient, is derived from rhizoma of Curcuma, which possesses antioxidant, antitumorigenic and anti-inflammatory activities. The present study aimed to investigate whether treatment with curcumin reduced high-fat diet (HFD)-induced spermatogenesis dysfunction. Sprague-Dawley rats fed a HFD were treated with or without curcumin for 8 weeks. The testis/body weight, histological analysis and serum hormone levels were used to evaluate the effects of curcumin treatment on spermatogenesis dysfunction induced by the HFD. In addition, the expression levels of apoptosis associated proteins, Fas, B-cell lymphoma (Bcl)-xl, Bcl-associated X protein (Bax) and cleaved-caspase 3 , were determined in the testis. The results of the present study suggested that curcumin treatment attenuated decreased testis/body weight and abnormal hormone levels. Morphological changes induced by a HFD were characterized as atrophied seminiferous tubules, decreased spermatogenetic cells and interstitial cells were improved by curcumin treatment. In addition, curcumin treatment reduced apoptosis in the testis, and decreased expression of Fas, Bax and cleaved-caspase 3, as well as increased expression of Bcl-xl. In conclusion, the present study revealed that curcumin treatment reduced HFD-induced spermatogenesis dysfunction in male rats.
\end{abstract}

\section{Introduction}

Infertility is defined as when couples who have an active sex life without using protective measures for $>1$ year, fail to get pregnant, which affects $10-15 \%(1,2)$. Of this, $\sim 25-30 \%$ are infertile couples due to problems with the man (3). Obesity, an acknowledged major risk factor for male infertility (4-6), leads

Correspondence to: Professor Jing Yang, Reproductive Medical Center, Renmin Hospital of Wuhan University, 238 Jiefang Road, Wuhan, Hubei 430060, P.R. China

E-mail: dryangqing@hotmail.com

*Contributed equally

Key words: curcumin, high-fat diet, spermatogenesis dysfunction, apoptosis to decreased sperm number and reproductive dysfunction $(7,8)$. Germ cell apoptosis in the testis is a key pathophysiological process in obesity-induced male spermatogenesis dysfunction (9), therefore inhibiting apoptosis in the testis may improve male spermatogeneses function.

Curcumin, a type of natural active ingredient derived from rhizoma of Curcuma, has protective effects in a series of diseases, including cardiovascular disease $(10,11)$, cancer, Alzheimer's disease (12) and diabetes (13). Curcumin has been previously found to serve a significant role in antioxidant, antimutative, anti-inflammatory and antitumorigenic responses (14-17), and recent studies indicated that curcumin can ameliorate high-glucose-induced neural defects by suppressing cellular stress and apoptosis (18). The present study investigated the hypothesis that curcumin treatment can improve spermatogenesis dysfunction induced by a high-fat diet (HFD). Testis/body weight, histological analysis and serum hormone levels were determined to reflect spermatogenesis function of adult rats. Since germ cell apoptosis is an important process during HFD-induced spermatogenesis dysfunction (9), apoptosis associated proteins, Fas, B-cell lymphoma ( $\mathrm{Bcl})-\mathrm{xl}, \mathrm{Bcl}$-associated $\mathrm{X}$ protein $(\mathrm{Bax})$ and cleaved-caspase 3 were also assessed.

\section{Materials and methods}

Animal care and treatment. A total of 30 male Sprague-Dawley rats (permit number, 42000500002649), weighing 200-250 g were used in the present study. All animals experiments performed in the present study were approved by the Institutional Animal Care and Use Committee of Renmin Hospital of Wuhan University (Wuhan, China). The animals were allowed free access to food and water at all times and were maintained on a $12 \mathrm{~h}$ light/dark cycle at a controlled temperature $\left(20-25^{\circ} \mathrm{C}\right)$ and humidity $(50 \pm 5 \%)$, which was also pathogen-free. The composition of the HFD is shown in Table I. Curcumin (Sigma-Aldrich, St. Louis, MO, USA) was dissolved by olive oil and administered orally by oral gavage. The rats were randomly divided into three groups: i) Control; ii) HFD; iii) curcumin treatment groups. All rats were subjected to a HFD for 8 weeks, with the exception of those in the control group ad libitum feeding. The rats in curcumin treatment group were orally administered curcumin treatment $(100 \mathrm{mg} / \mathrm{kg} / \mathrm{day})$ for 8 weeks, while in the control and HFD groups, an identical volume vehicle was used. Following treatment, the rats were 
anesthetized with sodium pentobarbital $(45 \mathrm{mg} / \mathrm{kg})$ intraperitoneally and blood samples were collected from the abdominal aorta. The rats were subsequently euthanized with $200 \mathrm{mg} / \mathrm{kg}$ sodium pentobarbital intraperitoneally and the testes were collected to calculate testis/body weight.

Histological analysis. The collected testis tissues were fixed with $4 \%$ paraformaldehyde, dehydrated and embedded in paraffin (Thermo Fisher Scientific, Inc., Waltham, MA, USA). The testis tissue sections $(5 \mu \mathrm{m})$ were sectioned with a microtome and stained with hematoxylin and eosin to examine the morphology. The tissue sections $(5 \mu \mathrm{m})$ were observed under light microscopy (Nikon E100; Nikon, Tokyo, Japan), and the photomicrographs were obtained by Photo Imaging System (Canon 600D; Canon, Tokyo, Japan). The diameter of seminiferous tubules was measured by Image-Pro Plus 6.0 (Media Cybernetics, Inc., Rockville, MD, USA). In each group, 120 seminiferous tubules (5 fields/rat, randomized 4 seminiferous tubules/field) in 6 rats' testes were counted. Additionally, 30 fields (5 fields/rat) in 6 rats/group were randomly selected to count spermatogenetic cells and interstitial cells.

Hormone levels assay. Blood samples were obtained from the abdominal aorta. Following centrifugation (1,506 x g) for $10 \mathrm{~min}$ at $4^{\circ} \mathrm{C}$, the sera were obtained for further detection. Serum levels of estradiol (E2), testosterone (T), follicle stimulating hormone (FSH), luteinizing hormone ( $\mathrm{LH})$ and leptin were measured using kits, according to the manufacturer's protocol (Elabscience Biotechnology Co., Ltd., Wuhan, China).

Immunohistochemistry. The protein expression levels of Fas, Bcl-xl and leptin receptors were tested by immunohistochemistry. The sections were deparaffinized and were subsequently boiled for $15 \mathrm{~min}$ in sodium citrate buffer for antigen retrieval. Following elimination of internal peroxidase activity, the sections were incubated with rabbit anti-Fas (1:50; cat no. BA0408), rabbit anti-leptin-receptor (1:50; cat no. BA1233; Wuhan Boster Biological Technology, Ltd., Wuhan, China) and rabbit anti-Bcl-xl (1:100; cat. no. 10783-AP; Proteintech Group, Inc., Chicago, IL, USA) antibodies at $4^{\circ} \mathrm{C}$ overnight. The tissue sections were exposed to biotinylated sheep anti-rabbit immunoglobulin G solution (Proteintech Group, Inc.) at $37^{\circ} \mathrm{C}$ for $30 \mathrm{~min}$ and were subsequently incubated with horseradish peroxidase-labeled streptavidin (Proteintech Group, Inc.) at $37^{\circ} \mathrm{C}$ for $30 \mathrm{~min}$. Finally, the tissue sections were observed under light microscopy (Nikon E100; Nikon), and the photomicrographs were obtained by Photo Imaging System (Canon 600D; Canon). In each group 30 fields ( 5 fields/rat) in 6 rat testis were randomly selected. Positive expression was assessed using Image-Pro Plus 6.0 and a mean of the integrated optical density was obtained.

Terminal deoxynucleotidyl transferase dUTP nick end labeling (TUNEL). Tissue sections were processed, according to the manufacturer's protocol for the TUNEL kit (Roche Applied Science, Indianapolis, IN, USA). Positively labeled nuclei were stained a brown color, while negatively labeled nuclei were blue. A total of 30 fields were randomly selected in each group ( 5 fields/rat) and 100 cells were counted in each
Table I. Macronutrient composition of diets for rats.

\begin{tabular}{lcccccc}
\hline & \multicolumn{2}{c}{ Control } & & \multicolumn{2}{c}{ High-fat diet } \\
\cline { 2 - 3 } Nutrient & $\mathrm{g}, \%$ & $\mathrm{~kJ}, \%$ & & $\mathrm{~g}, \%$ & $\mathrm{~kJ}, \%$ \\
\hline Protein & 20 & 19 & & 20 & 14 \\
Carbohydrate & 76 & 72 & & 45 & 31 \\
Saturated fat & 4 & 9 & & 35 & 55 \\
$\mathrm{~kJ} / \mathrm{g}$ & 17.5 & & & 24.1 & \\
\hline
\end{tabular}

field under a microscope (Nikon E100; Nikon), and the number of positive cells was recorded. The apoptosis index (number of apoptotic cells in each field/100) was computed for each field.

Western blot analysis. Lysis buffer (720 $\mu 1$ radioimmunoprecipitation buffer, $100 \mathrm{mmol} / \mathrm{l} \mathrm{PMSF}, 100 \mu \mathrm{l}$ cocktail, $100 \mu \mathrm{l}$ Phos-stop, $20 \mathrm{mmol} / \mathrm{l} \mathrm{NaF}$ and $100 \mathrm{mmol} / 1 \mathrm{Na}_{3} \mathrm{VO}_{4}$ in $1 \mathrm{ml}$ ) was used to extract the total proteins from fresh testicular tissues. The protein concentrations were tested using the Bicinchoninic Acid Protein Assay kit (Thermo Fisher Scientific, Inc.) and a plate reader (Bio-Tek Instruments, Inc., Winooski, VT, USA). Equal quantities of protein $(30 \mu \mathrm{g})$ were separated with denaturing sodium dodecyl sulphate $10 \%$ polyacrylamide gels under reducing and denaturing conditions and were subsequently transferred onto a polyvinylidene difluoride (PVDF) membrane (EMD Millipore, Billerica, MA, USA). The PVDF membrane was blocked with $5 \%$ (w/v) non-fat milk and $0.1 \%$ Tween in Tris-buffered saline ( $\mathrm{pH} 7.4$ ) at room temperature for $1 \mathrm{~h}$. Following blocking, the membrane was incubated overnight at $4^{\circ} \mathrm{C}$ with the following rabbit primary antibodies: Anti-GAPDH antibody (1:200; Santa Cruz Biotechnology, Inc., Santa Cruz, CA, USA; cat. no. sc-25778), anti-Bax antibody (1:1,000; Cell Signaling Technology, Inc., Danvers, MA, USA; cat. no. 14796) and anti-cleaved-caspase 3 antibody (1:1,000; Cell Signaling Technology, Inc.; cat. no. 9664). Following the incubation with primary antibody, the membrane was incubated with IRDye $800 \mathrm{CW}$-conjugated secondary antibody (LI-COR Biosciences, Lincoln, NE, USA; cat. no. 926-32211) for $1 \mathrm{~h}$. Finally, the membrane was scanned using a two-color infrared imaging system (Odyssey, LI-COR Biosciences). Densitometric analysis was performed by Odyssey, as previous described (19), and the results were expressed as the ratio between targeted proteins and GAPDH band intensities.

Statistical analysis. All statistical analyses were performed with SPSS 19.0 (IBS SPSS, Chicago, IL, USA). All data are expressed as the mean \pm standard error of the mean. Multiple group comparison was performed by analysis of variance, followed by the post-hoc least significant difference test assuming equal variances; otherwise Tamhane's T2 post-hoc test. All statistical analyses were two-sided. $\mathrm{P}<0.05$ was considered to indicate a statistically significant difference.

\section{Results}

Histomorphological changes. Following a HFD for 8 weeks, the testis/body weight was reduced and treatment with 
A

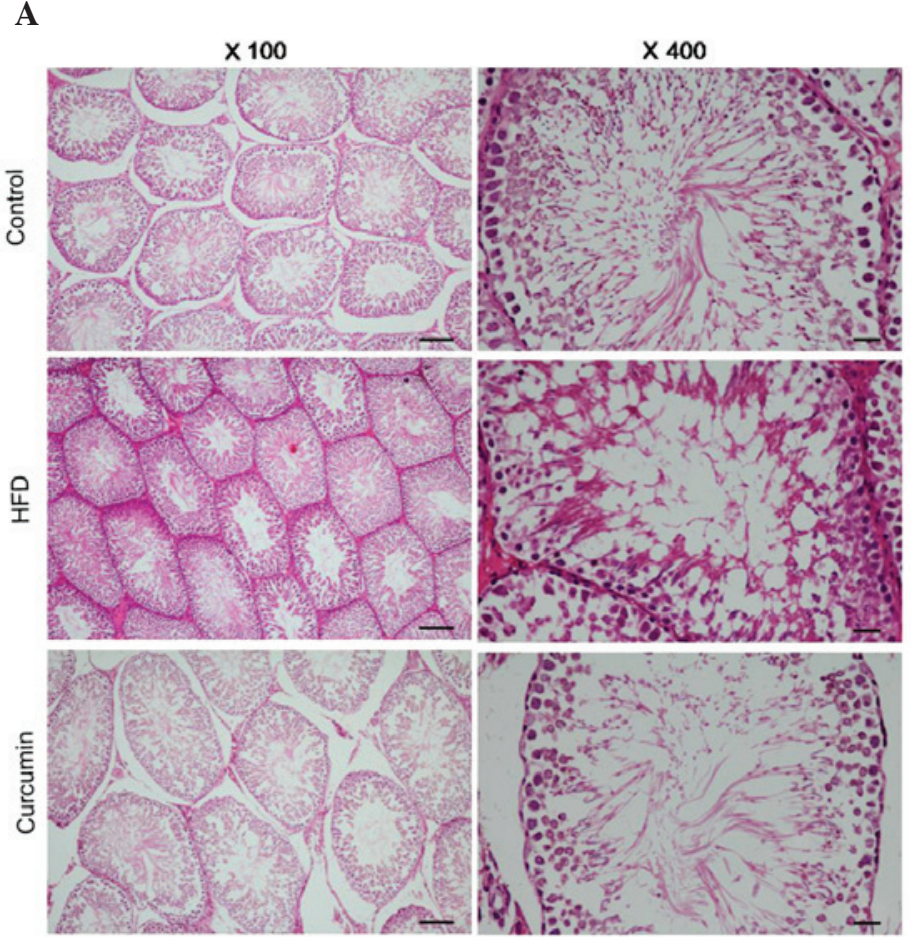

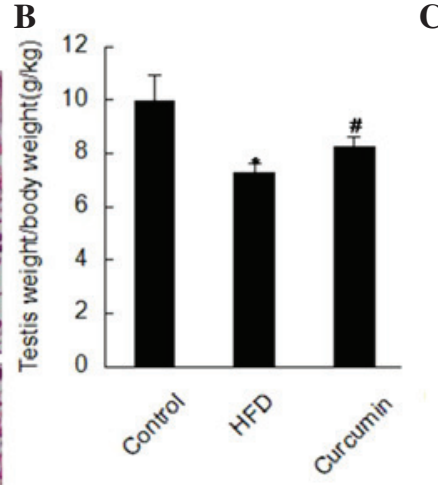
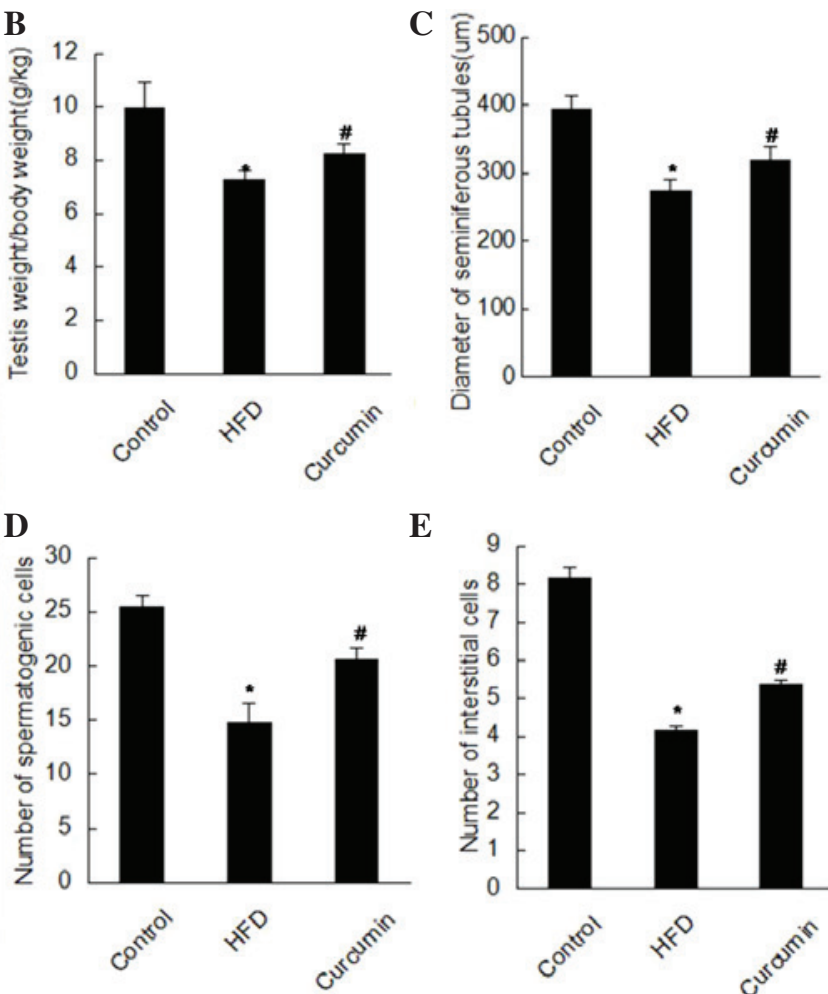

$\mathbf{E}$

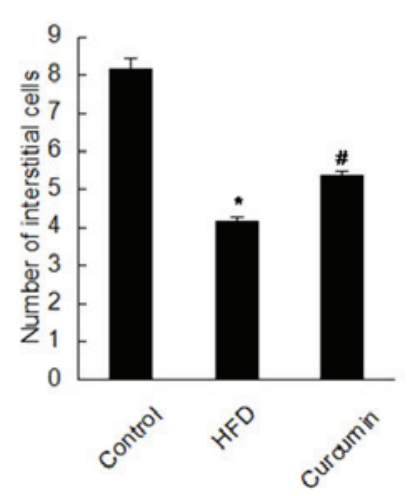

Figure 1. Oral treatment with curcumin prevents HFD-induced male spermatogenesis dysfunction. (A) Hematoxylin and eosin staining of the testis in the three groups ( $\mathrm{n}=6$; magnification, $\mathrm{x} 100$ and x400; scale bar, 100 and $20 \mu \mathrm{m}$ on the left and right, respectively). (B) Testicular/body weight was determined for the three groups $(n=10)$. (C-E) Quantitative analysis of morphological changes of the testis in three groups are presented $(n=6)$. The data are expressed as the mean \pm standard error of the mean $\left({ }^{*} \mathrm{P}<0.05\right.$, HFD vs. control group; ${ }^{\mathrm{P}}<0.05$, curcumin treatment vs. HFD group. HFD, high-fat diet.

A
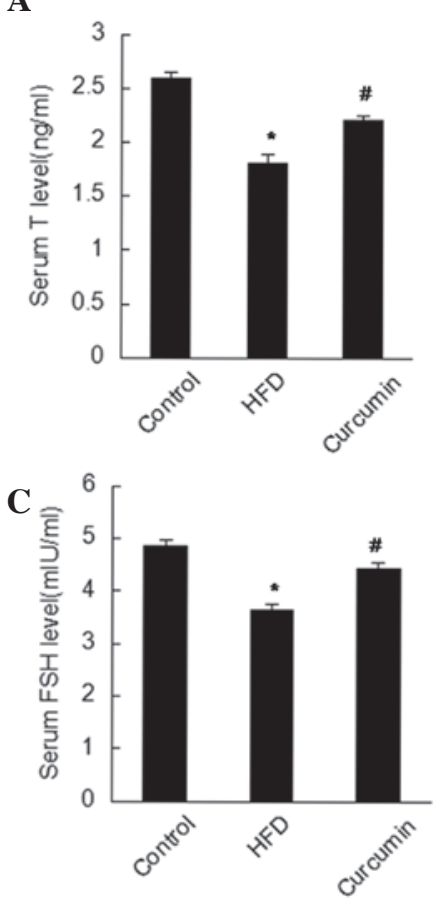

B
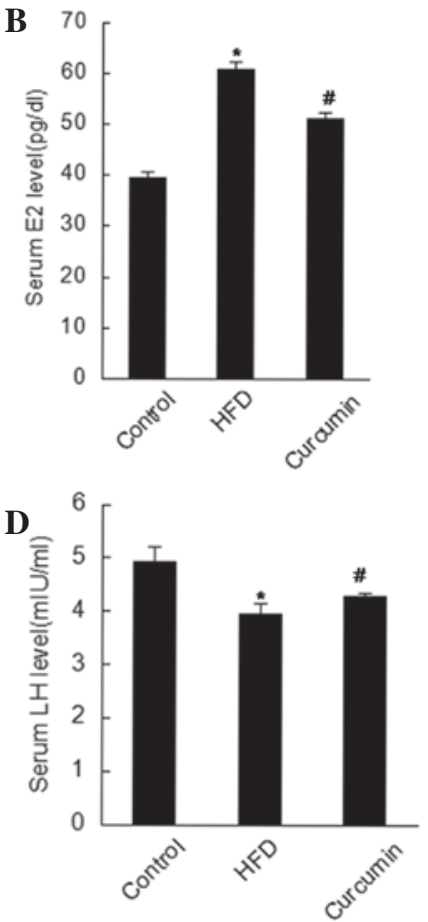

Figure 2. Curcumin treatment improves defective serum hormone levels of (A) T, (B) E2, (C) FSH and (D) LH induced by HFD. (n=8; * $<<0.05$, HFD vs. control group; ${ }^{\text {P }}<0.05$, curcumin treatment group vs. HFD group). FSH, follicle-stimulating hormone; LH, luteinizing hormone; T, testosterone; E2, estradiol; HFD, high-fat diet.

curcumin increased the testis/body weight (Table II; Fig. 1). The testicular structure of the control group under the light microscope manifested as larger seminiferous tubules, abundant spermatogenetic and interstitial cells. As shown in Fig. 1, atrophic seminiferous tubules and more vacuoles were observed in the HFD group. Notably, decreased spermatogenetic and 
Table II. Testicular weight and testicular/body weight of the three groups.

\begin{tabular}{|c|c|c|c|c|}
\hline Group & $\mathrm{n}$ & $\begin{array}{c}\text { Body } \\
\text { weight (g) }\end{array}$ & $\begin{array}{l}\text { Testicular } \\
\text { weight }(\mathrm{g})\end{array}$ & $\begin{array}{c}\text { Testicular/body } \\
\text { weight (g/kg) }\end{array}$ \\
\hline Control & 10 & $315.80 \pm 14.74$ & $3.14 \pm 0.21$ & $9.97 \pm 0.93$ \\
\hline High-fat diet & 10 & $371.40 \pm 12.05^{\mathrm{a}}$ & $2.70 \pm 0.16^{\mathrm{a}}$ & $7.27 \pm 0.35^{\mathrm{a}}$ \\
\hline Curcumin & 10 & $353.20 \pm 5.76$ & $2.90 \pm 0.12^{b}$ & $8.21 \pm 0.38^{b}$ \\
\hline
\end{tabular}

The data are expressed as the mean \pm standard error of the mean. ${ }^{\mathrm{P}}<0.05$ vs. control group; ${ }^{\mathrm{b}}<0.05$ vs. high-fat diet group.

A

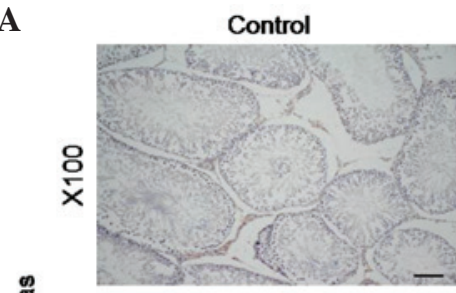

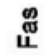

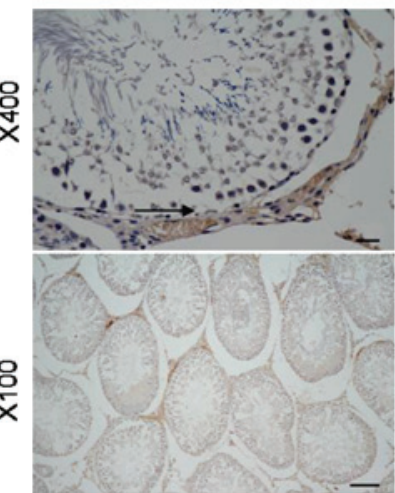

产
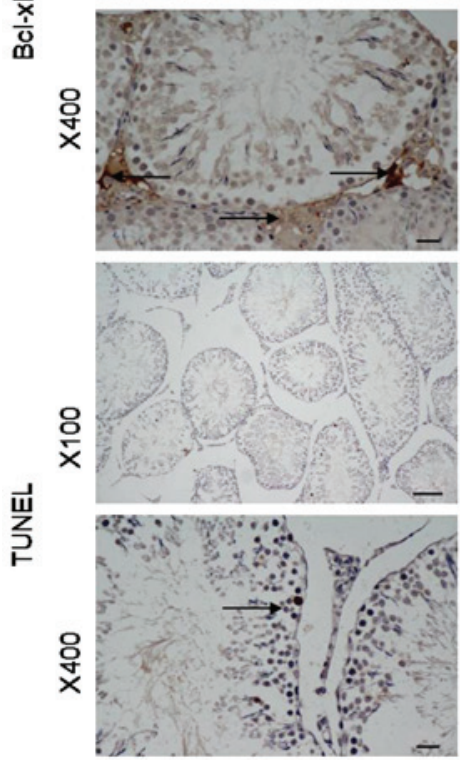
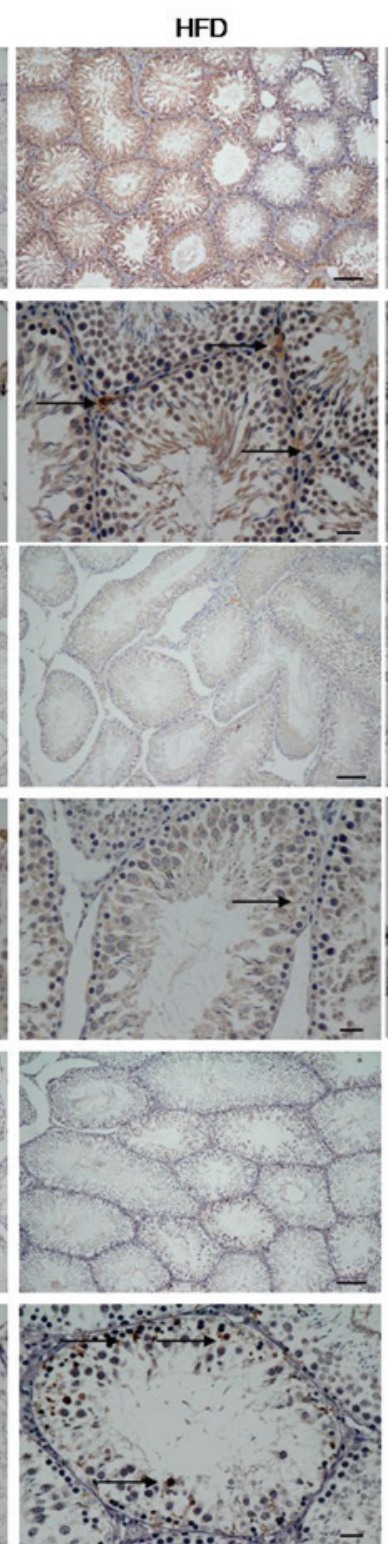
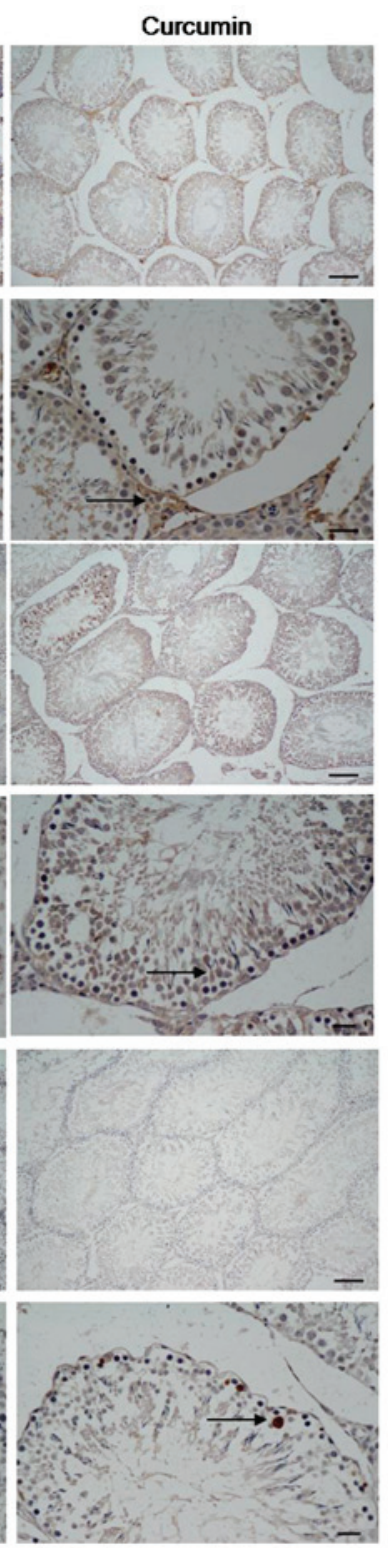
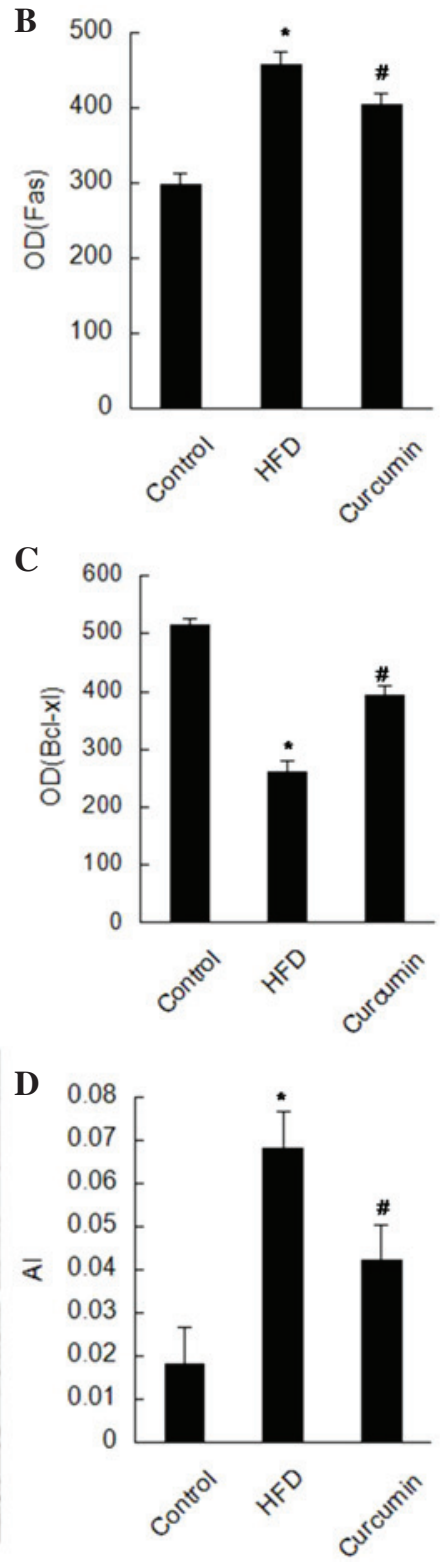

Figure 3. Curcumin supplementation attenuates apoptosis in the testis. (A) Immunohistochemical staining for the protein expression levels of Bcl-xl and Fas, and TUNEL for the apoptotic cells in the testis (n=6; magnification x100 and x400; scale bar 100 and $20 \mu \mathrm{m}$ on the upper and lower panels, respectively). Bcl-xl and Fas are predominantly observed in the interstitial cells. Arrows indicate positive expression. (B-D) Quantitative analysis of AI and the OD (n=6). The data are expressed as the mean \pm standard error of the mean $\left({ }^{*} \mathrm{P}<0.05, \mathrm{HFD}\right.$ vs. control group; ${ }^{\#} \mathrm{P}<0.05$, curcumin vs. HFD group). HFD, high-fat diet; Bcl, B-cell lymphoma; OD, optical density; AI, apoptosis index; TUNEL, terminal deoxynucleotidyl transferase dUTP nick end labeling.

interstitial cells were observed in the HFD group. However, these histological changes were improved following treatment with curcumin (Table III; Fig. 1).
Determination of endogenous hormone. Rats fed with an HFD exhibited abnormal serum hormone levels, manifested as reduced serum levels of T, FSH and $\mathrm{LH}$, and increased serum 
A

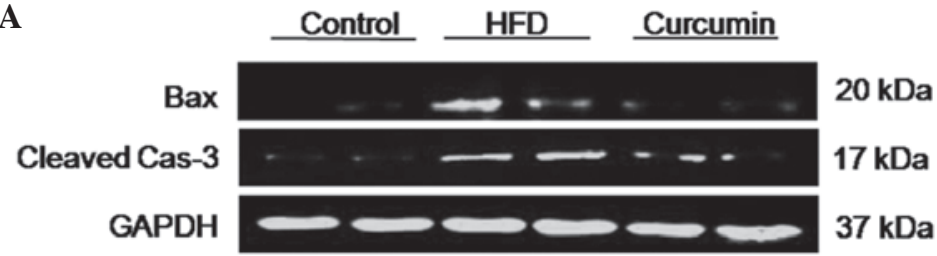

B

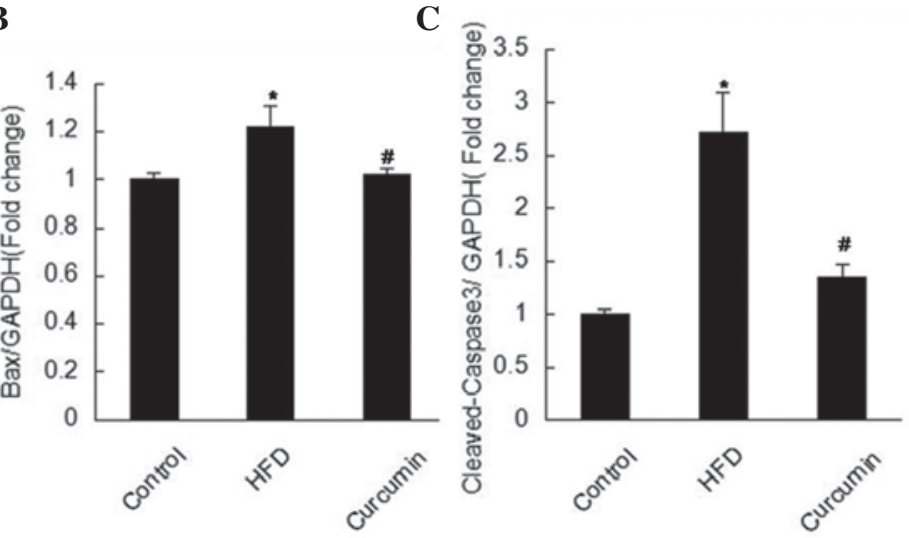

Figure 4. Curcumin treatment reduces apoptosis-associated protein expression levels of Bax and cleaved-cas-3. (A) Western blotting analysis of the protein expression levels of Bax and cleaved-cas-3 was assessed in the testis tissues from the three groups $(\mathrm{n}=4)$. The fold-change in protein expression levels of (B) Bax and (C) cleaved-cas-3 was quantified relative to the expression of GAPDH. The data are expressed as the mean \pm standard error of the mean ("P $<0.05$, HFD vs. control group; ${ }^{\#} \mathrm{P}<0.05$, curcumin vs. HFD group. HFD, high-fat diet; cas, caspase; Bax, B-cell lymphoma associated $\mathrm{X}$ protein.

A

음
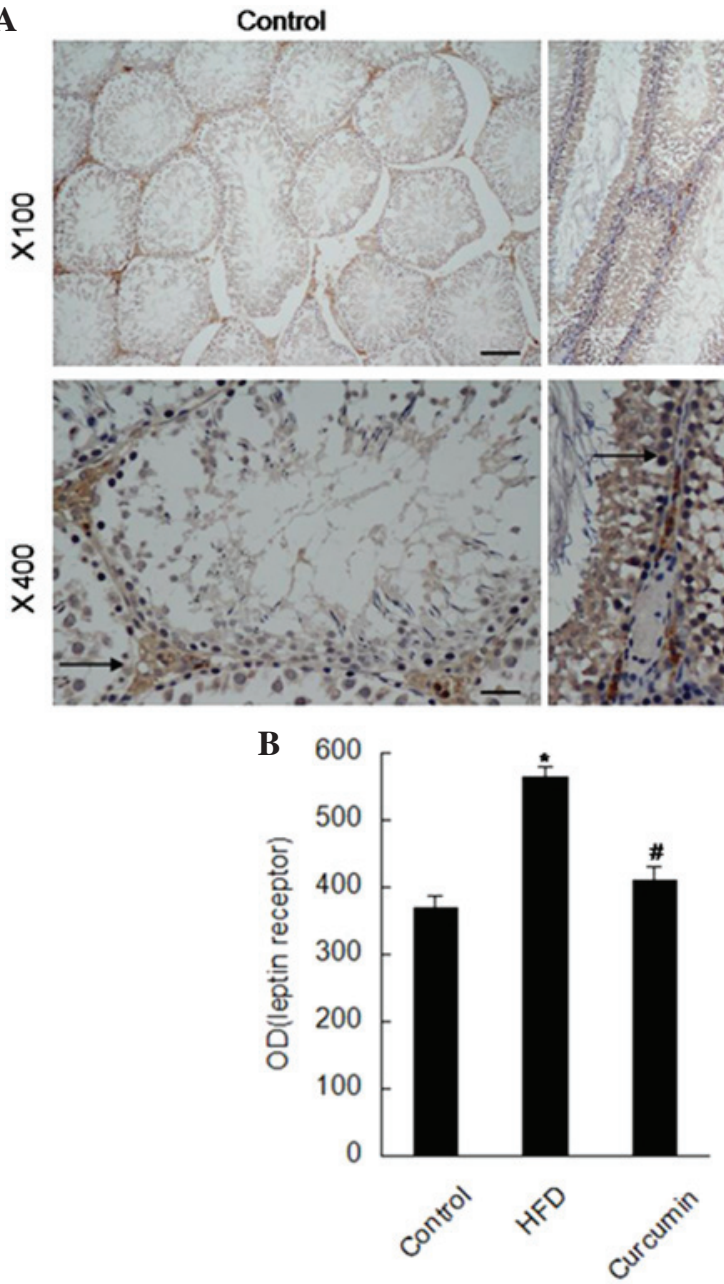

HFD
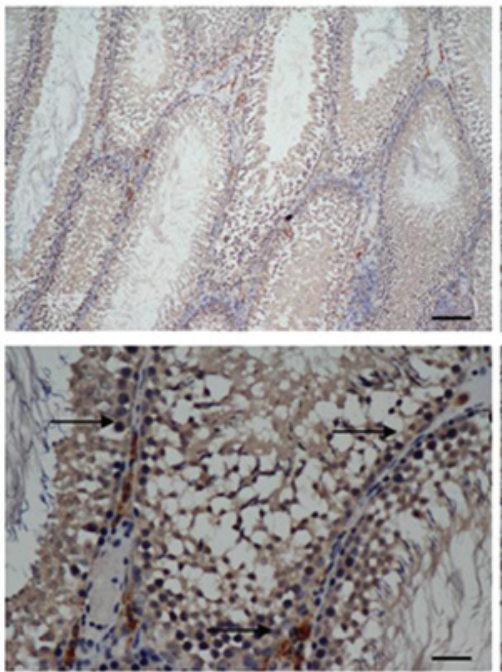
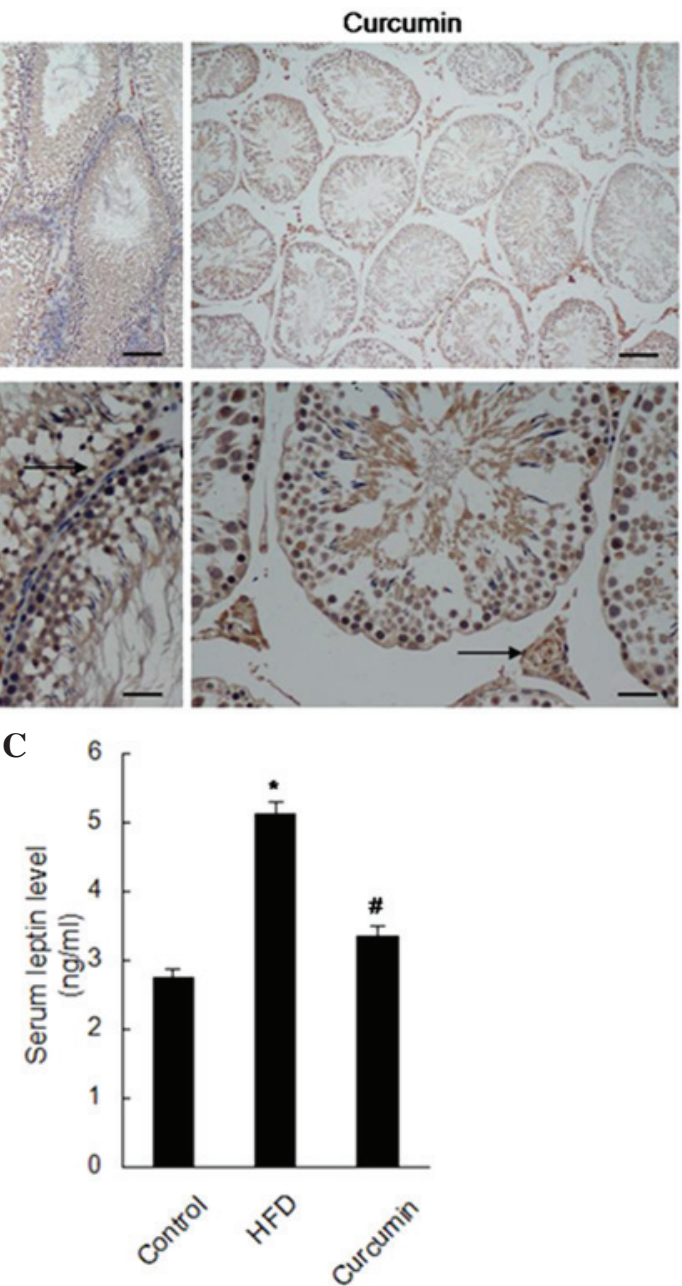

Figure 5. Curcumin treatment decreases the expression of leptin receptors and reduces serum leptin level. (A) Immunohistochemical staining for the expression of leptin receptors in the testis ( $\mathrm{n}=6$; magnification $\mathrm{x} 100$ and $\mathrm{x} 400$; scale bar 100 and $20 \mu \mathrm{m}$ on the upper and lower panels, respectively). Arrows indicate positive expression. (B) The mean OD of leptin receptors $(n=6)$ and $(C)$ serum leptin levels $(n=8)$ were quantified. The data are expressed as the mean \pm standard error of the mean $\left({ }^{*} \mathrm{P}<0.05\right.$, HFD vs. control; ${ }^{*} \mathrm{P}<0.05$, curcumin vs. HFD group). HFD, high-fat diet; OD, optical density. 
Table III. Comparison of diameters of seminiferous tubules and the quantity of spermatogenetic cells and interstitial cells in the three groups.

\begin{tabular}{lcccc}
\hline Group & $\mathrm{n}$ & $\begin{array}{c}\text { Seminiferous tubule } \\
\text { diameter }(\mu \mathrm{m})\end{array}$ & $\begin{array}{c}\text { Quantity of } \\
\text { spermatogenetic cells }\end{array}$ & $\begin{array}{c}\text { Quantity of } \\
\text { interstitial cells }\end{array}$ \\
\hline Control & 6 & $395.08 \pm 19.91$ & $25.40 \pm 1.14$ & $8.16 \pm 0.29$ \\
High-fat diet & 6 & $273.70 \pm 16.55^{\mathrm{a}}$ & $14.80 \pm 1.79^{\mathrm{a}}$ & $4.16 \pm 0.12^{\mathrm{a}}$ \\
Curcumin & 6 & $319.94 \pm 20.55^{\mathrm{b}}$ & $20.60 \pm 1.14^{\mathrm{b}}$ & $5.37 \pm 0.11^{\mathrm{b}}$ \\
\hline
\end{tabular}

The data are expressed as the mean \pm standard error of the mean. ${ }^{\mathrm{a}} \mathrm{P}<0.05$ vs. control group; ${ }^{\mathrm{b}} \mathrm{P}<0.05$ vs. HFD group.

levels of leptin and E2. Serum hormone levels were observed to be restored following treatment with curcumin (Figs. 2 and 5).

Expression levels of apoptosis associated proteins and leptin receptors. A HFD resulted in more apoptotic cells in the testis, characterized by elevated expression levels of Fas, Bax and cleaved-caspase 3 , and reduced expression of Bcl-xl. Following treatment with curcumin, these changes were attenuated (Figs. 3 and 4). The expression of leptin receptors was found to be increased in the testis of rats fed a HFD by immunohistochemistry staining, and curcumin treatment reduced these increased leptin receptors (Fig. 5).

\section{Discussion}

In order to investigate the effects of curcumin on male spermatogenesis function, the present study subjected the rats to a HFD to induce spermatogenesis dysfunction. The present results revealed that spermatogenesis function was disturbed in rats fed with a HFD, characterized as decreased testis/body weight, atrophied seminiferous tubules, reduced spermatogenetic and interstitial cells, and abnormal hormone levels, which is consistent with a previous study (7).

Curcumin has been demonstrated to have a series of pharmacological actions, including antioxidant, antimutative, anti-inflammatory and antitumorigenic actions (14-17). Over the last decade, the therapeutic effects of curcumin on various cancer types and Alzheimer's disease have been confirmed by clinical trials (20). The present study found that curcumin treatment improved atrophied testes manifested as increased testis/body weight, increased the diameter of seminiferous tubules, and increased the number of spermatogenetic and interstitial cells. Additionally, curcumin treatment improved the abnormal hormone levels. Taken together, curcumin had protective effects in HFD-induced spermatogenesis dysfunction.

The balance between cell proliferation and cell death is important in spermatogenesis function. As a type of cell death, apoptosis of testicular germ cells was an important physiological mechanism in regulating the germ cell population (21-24). Increased germ cell apoptosis was observed in testicular injury induced by stimuli (25-28), and additionally, suppressing apoptosis improved the sperm count (29-33). As shown in the present results, curcumin treatment decreased the protein expression levels of Fas, Bax and cleaved-caspase 3 and increased the expression of Bcl-xl. Notably, curcumin treatment reduced germ cell apoptosis induced by a HFD.
Leptin, also synthesized by seminiferous tubules $(34,35)$, was found to have important effects on reproductive function (36), which has been confirmed by sterile leptin deficient $o b$ mice (37). Additionally, leptin directly acted on the testis and modulated spermatogenesis (38). In addition, leptin served an inhibitory role in testicular steroidogenesis $(39,40)$ and influenced the weight of the testis, the diameter of seminiferous tubules and the number of germ cells (41). In the present study, the leptin receptors in the testis and serum leptin level were increased in rats subjected to a HFD. Treatment with curcumin downregulated the increased levels of leptin receptors and the serum leptin level.

In conclusion, the present study revealed that curcumin reduced HFD-induced spermatogenesis dysfunction and apoptosis. Curcumin may be a potential novel therapeutic medicine for male patients suffering from obesity-induced infertility.

\section{Acknowledgements}

The present study was partially supported by the Key Research Project of the Ministry of Public Security (no. 2010 ZDYJHBST007)

\section{References}

1. Botelho F, Figueiredo L, Leite R, Carvalho A, Tomada N and Vendeira P: Predictive factors of a successful testicular biopsy and subsequent clinical pregnancy. Andrologia 44: 237-242, 2012.

2. Ferlin A, Arredi B and Foresta C: Genetic causes of male infertility. Reprod Toxicol 22: 133-141, 2006

3. Hammoud AO, Gibson M, Peterson CM, Hamilton BD and Carrell DT: Obesity and male reproductive potential. J Androl 27: 619-626, 2006.

4. Pasquali R, Pelusi C, Genghini S, Cacciari M and Gambineri A: Obesity and reproductive disorders in women. Hum Reprod Update 9: 359-372, 2003.

5. Pantasri $\mathrm{T}$ and Norman RJ: The effects of being overweight and obese on female reproduction: A review. Gynecol Endocrinol 30: 90-94, 2014.

6. Jungheim ES, Travieso JL and Hopeman MM: Weighing the impact of obesity on female reproductive function and fertility. Nutr Rev 71 (Suppl 1): S3-S8, 2013.

7. Jensen TK, Andersson AM, Jørgensen N, Andersen AG, Carlsen E, Petersen JH and Skakkebaek NE: Body mass index in relation to semen quality and reproductive hormones among 1,558 Danish men. Fertil Steril 82: 863-870, 2004.

8. Kort HI, Massey JB, Elsner CW, Mitchell-Leef D, Shapiro DB, Witt MA and Roudebush WE: Impact of body mass index values on sperm quantity and quality. J Androl 27: 450-452, 2006.

9. Palmer NO, Bakos HW, Owens JA, Setchell BP and Lane M: Diet and exercise in an obese mouse fed a high-fat diet improve metabolic health and reverse perturbed sperm function. Am J Physiol Endocrinol Metab 302: E768-E780, 2012. 
10. Srivastava G and Mehta JL: Currying the heart: Curcumin and cardioprotection. J Cardiovasc Pharmacol Ther 14: 22-27, 2009.

11. Wongcharoen W and Phrommintikul A: The protective role of curcumin in cardiovascular diseases. Int J Cardiol 133: 145-151, 2009.

12. Shen L and Ji HF: The pharmacology of curcumin: Is it the degradation products? Trends Mol Med 18: 138-144, 2012.

13. Maheshwari RK, Singh AK, Gaddipati J and Srimal RC: Multiple biological activities of curcumin: A short review. Life Sci 78 : 2081-2087, 2006.

14. Li M, Zhang Z, Hill DL, Wang $\mathrm{H}$ and Zhang R: Curcumin, a dietary component, has anticancer, chemosensitization and radiosensitization effects by down-regulating the MDM2 oncogene through the PI3K/mTOR/ETS2 pathway. Cancer Res 67: 1988-1996, 2007.

15. Bruck R, Ashkenazi M, Weiss S, Goldiner I, Shapiro H, Aeed H, Genina O, Helpern Z and Pines M: Prevention of liver cirrhosis in rats by curcumin. Liver Int 27: 373-383, 2007.

16. Shakibaei M, John T, Schulze-Tanzil G, Lehmann I and Mobasheri A: Suppression of NF-kappaB activation by curcumin leads to inhibition of expression of cyclo-oxygenase- 2 and matrix metalloproteinase-9 in human articular chondrocytes: Implications for the treatment of osteoarthritis. Biochem Pharmacol 73: 1434-1445, 2007.

17. Shen SQ, Zhang Y, Xiang JJ and Xiong CL: Protective effect of curcumin against liver warm ischemia/reperfusion injury in rat model is associated with regulation of heat shock protein and antioxidant enzymes. World J Gastroenterol 13: 1953-1961, 2007.

18. Wu Y, Wang F, Reece EA and Yang P: Curcumin ameliorates high glucose-induced neural tube defects by suppressing cellular stress and apoptosis. Am J Obstet Gynecol 212: 802.e1-e8, 2015.

19. Liu Y, Jiang XL, Liu Y, Jiang DS, Zhang Y, Zhang R, Chen Y, Yang Q, Zhang XD, Fan GC and Li H: Toll-interacting protein (Tollip) negatively regulates pressure overload-induced ventricular hypertrophy in mice. Cardiovasc Res 101: 87-96, 2014.

20. Hatcher H, Planalp R, Cho J, Torti FM and Torti SV: Curcumin: From ancient medicine to current clinical trials. Cell Mol Life Sci 65: 1631-1652, 2008.

21. Allan DJ, Harmon BV and Roberts SA: Spermatogonial apoptosis has three morphologically recognizable phases and shows no circadian rhythm during normal spermatogenesis in the rat. Cell Prolif 25: 241-250, 1992.

22. Bartke A: Apoptosis of male germ cells, a generalized or a cell type-specific phenomenon? Endocrinology 136: 3-4, 1995.

23. Billig H, Furuta I, Rivier C, Tapanainen J, Parvinen M and Hsueh AJ: Apoptosis in testis germ cells: Developmental changes in gonadotropin dependence and localization to selective tubule stages. Endocrinology 136: 5-12, 1995.

24. Hikim AP, Wang C, Leung A and Swerdloff RS: Involvement of apoptosis in the induction of germ cell degeneration in adult rats after gonadotropin-releasing hormone antagonist treatment. Endocrinology 136: 2770-2775, 1995

25. Lee J, Richburg JH, Shipp EB, Meistrich ML and Boekelheide K: The Fas system, a regulator of testicular germ cell apoptosis, is differentially up-regulated in Sertoli cell versus germ cell injury of the testis. Endocrinology 140: 852-858, 1999.
26. Sinha HA, Rajavashisth TB, SinhaHikim I, Lue Y, Bonavera JJ, Leung A, Wang C and Swerdloff RS: Significance of apoptosis in the temporal and stage-specific loss of germ cells in the adult rat after gonadotropin deprivation. Biol Reprod 57: 1193-1201, 1997.

27. Yin Y, DeWolf WC and Morgentaler A: Experimental cryptorchidism induces testicular germ cell apoptosis by p53-dependent and -independent pathways in mice. Biol Reprod 58: 492-496, 1998.

28. Hasegawa M, Zhang Y, Niibe H, Terry NH and Meistrich ML: Resistance of differentiating spermatogonia to radiation-induced apoptosis and loss in p53-deficient mice. Radiat Res 149: 263-270, 1998.

29. Hockenbery DM, Oltvai ZN, Yin XM, Milliman CL and Korsmeyer SJ: Bcl-2 functions in an antioxidant pathway to prevent apoptosis. Cell 75: 241-251, 1993.

30. Kane DJ, Sarafian TA, Anton R, Hahn H, Gralla EB, Valentine JS, Ord T and Bredesen DE: Bcl-2 inhibition of neural death: Decreased generation of reactive oxygen species. Science 262: 1274-1277, 1993

31. Wong WY, Merkus HM, Thomas CM, Menkveld R, Zielhuis GA and Steegers-Theunissen RP: Effects of folic acid and zinc sulfate on male factor subfertility: A double-blind, randomized, placebo-controlled trial. Fertil Steril 77: 491-498, 2002.

32. Joshi R, Adhikari S, Patro BS, Chattopadhyay S and Mukherjee T: Free radical scavenging behavior of folic acid: Evidence for possible antioxidant activity. Free Radic Biol Med 30: 1390-1399, 2001.

33. Zago MP and Oteiza PI: The antioxidant properties of zinc: Interactions with iron and antioxidants. Free Radic Biol Med 31: 266-274, 2001

34. Campfield LA, Smith FJ and Burn P: The OB protein (leptin) pathway-a link between adipose tissue mass and central neural networks. Horm Metab Res 28: 619-632, 1996.

35. Glander HJ, Lammert A, Paasch U, Glasow A and Kratzsch J: Leptin exists in tubuli seminiferi and in seminal plasma. Andrologia 34: 227-233, 2002.

36. Caprio M, Fabbrini E, Isidori AM, Aversa A and Fabbri A: Leptin in reproduction. Trends Endocrinol Metab 12: 65-72, 2001.

37. Zhang Y, Proenca R, Maffei M, Barone M, Leopold L and Friedman JM: Positional cloning of the mouse obese gene and its human homologue. Nature 372: 425-432, 1994

38. Ma Y, Chen B, Wang H, Hu K and Huang Y: Prediction of sperm retrieval in men with non-obstructive azoospermia using artificial neural networks: Leptin is a good assistant diagnostic marker. Hum Reprod 26: 294-298, 2011.

39. Fui MN, Dupuis P and Grossmann M: Lowered testosterone in male obesity: Mechanisms, morbidity and management. Asian J Androl 16: 223-231, 2014.

40. Isidori AM, Caprio M, Strollo F, Moretti C, Frajese G, Isidori A and Fabbri A: Leptin and androgens in male obesity: Evidence for leptin contribution to reduced androgen levels. J Clin Endocrinol Metab 84: 3673-3680, 1999.

41. Yuan M, Huang G, Li J, Zhang J, Li F, Li K, Gao B, Zeng L, Shan W, Lin P and Huang L: Hyperleptinemia directly affects testicular maturation at different sexual stages in mice and suppressor of cytokine signaling 3 is involved in this process. Reprod Biol Endocrinol 12: 15, 2014. 